\author{
Urszula Ostrowska* \\ ORCID: 0000-0003-2280-706X \\ Bydgoszcz
}

\title{
Droga do wolności jako dramat. Wokół Tischnerowskiej koncepcji filozofii wolności
}

Namysł nad intelektualnym dziedzictwem filozofa, teologa, eseisty, księdza Józefa Tischnera, zwłaszcza nad zajmującą ważne miejsce w jego refleksji koncepcją wolności z perspektywy autorskiej filozofii dramatu, fascynująco inspiruje do odczytywania płynącego z owej bogatej spuścizny przesłania. Podążanie tropem Tischnerowskiego „myślenia z wnętrza metafory" umożliwia odkrywanie architektoniki kreowanej przez filozofa drogi do wolności człowieka jako istoty dramatycznej. W przekonaniu ,myśliciela z wnętrza metafory" to właśnie język metaforyczny jest najwłaściwszy w dociekaniu istoty tajemnicy człowieka i jego doświadczenia. $\mathrm{W}$ istocie metafora jako szczególny przypadek analogii - sytuując się pomiędzy dosłownością a przenośnią - uwyraźnia niepewność i nieoczywistość losu człowieka oraz jego świata, wychodząc naprzeciw dramatycznemu wymiarowi owego uniwersum $^{2}$. Nic przeto dziwnego, że owa określająca człowieka jako istotę

* Prof. zw. dr hab. Urszula Ostrowska jest profesorem Akademii im. Jakuba z Paradyża w Gorzowie Wielkopolskim. Adres: Akademii im. Jakuba z Paradyża, ul. Teatralna 25, 66-400 Gorzów Wielkopolski; e-mail: urszula.ostrowska@wp.pl.

1 Józef Tischner, Myślenie wedtug wartości (Kraków: Znak, 1993).

${ }^{2}$ Zagadnienie metafory podejmowałam z innej perspektywy problemowej i przy innej okazji. Zob. Urszula Ostrowska, Dialog w pedagogicznym badaniu jakościowym (Kraków: Oficyna Wydawnicza „Impuls”, 2000), 99-114 i passim. 
dramatyczną metafora stanowi fundament całej Tischnerowskiej koncepcji filozofii dramatu, w której elementy symboliki teatralnej, takie mianowicie jak: scena, maska, dramat, droga etc., służą opisowi człowieka i jego świata z perspektywy całokształtu egzystencji ludzkiej, umożliwiając lepsze jego rozumienie, wnikliwsze poznawanie osoby jako istoty dramatycznej przeżywającej dany czas oraz mającej ,,wokół siebie innych ludzi i ziemię jako scenę pod stopami"’3.

Podjętą w niniejszym tekście problematykę konstruują niezwykle nośne z perspektywy różnych dyscyplin naukowych, zwłaszcza społecznych $\mathrm{i}$ humanistycznych, $\mathrm{w}$ tym nauk o literaturze i o sztuce, ale przede wszystkim kluczowe dla kreowanego przez autora „myślenia według wartości” świata kategorie: droga, wolność, dramat, składające się na jego filozofię wolności. Wypada rozpocząc od wchodzącej w skład pierwszej frazy tematu: „droga do wolności" bogatego semantycznie i zakorzenionego twórczo w filozoficznej tradycji terminu „droga”, który w swej różnorodności towarzyszy człowiekowi od zarania dziejów. Dla tejże kategorii przyjmuję perspektywę wglądu przez pryzmat Tischnerowskiej drogi do wolności jako dramatu.

\section{Droga}

W kulturze funkcjonuje mocno zakorzeniony topos życia ludzkiego jako nieustannej wędrówki, przypisujący człowiekowi miano Homo viator (z łac. „podróżny”, „pielgrzym”), istoty będącej w drodze, podróżującej z jednego do drugiego miejsca, ale także osoby uczestniczącej w ubogaconej w konteksty drodze-procesie - w podróży, wędrówce, tułaczce, pielgrzymce przez całe życie - jak to ujmował Józef Tischner - od narodzin poprzez śmierć aż do nieskończoności ${ }^{4}$.

Ową drogę-proces konstruują serie mniej więcej jednorodnych zjawisk występujących w określonym czasie i w przestrzeni, obejmując swym zakresem następstwo zdarzeń, łączność z kimś, z czymś, sposób bądź tryb załatwiania jakiejś sprawy, jak również ewentualność rozstrzygania określonych kwestii, a także dochodzenie do sensu, wartości, walorów kogoś, czegoś, w tym doświadczania wartości samego siebie oraz otaczającej rzeczywistości.

3 Józef Tischner, Filozofia dramatu (Kraków: Znak, 1993), 7.

${ }^{4}$ Ów symbol człowieczej doli i topos osoby będącej w drodze, w podróży, w tułaczce, którego archetypem literackim jest bohater epopei Homera - Odyseusz - dość często bywa źródłem inspiracji dla twórców reprezentujących różne dziedziny nauki i sztuki. 
Niemniej poznawanie kogoś/czegoś albo odsłanianie nowego i egzystencjalnie znaczącego z natury rzeczy nie bywa łatwe, toteż owa droga zazwyczaj okazuje się w swej istocie nader skomplikowana, czasem kręta i wyboista, bez pewności i jasności w kwestii dokonywanych wyborów. Nadto niejednokrotnie będąc niewolna od rozmaitych pułapek, droga może zawieść na rozstaje bądź w ślepe zaułki i doprowadzić do zagubienia się lub skłaniać ku powrotom „tam i z powrotem”. Owe powroty, jeśli nie są postrzegane li tylko przez pryzmat ,zwykłego powtórzenia”, wzbogacają człowieka w peregrynacyjne doświadczenie, otwierając przed nim nowe perspektywy ${ }^{5}$.

W istocie przyznać trzeba, że ten, kto pokonuje drogę, kto pielgrzymuje, niejednokrotnie narażony bywa na niebezpieczeństwo błądzenia. Zwłaszcza w obcej okolicy w obliczu skomplikowanej, niewystarczająco rozpoznanej materii, łatwo zagubić drogę, jej sens i istotę. Kto błądzi - jak zwraca uwagę Tischner w Wędrówkach w krainę filozofów, odnosząc się do rozprawy Martina Heideggera Co to znaczy myśleć - ten gubi nie tylko drogę, ale także może zagubić siebie ${ }^{6}$.

Kwestia tego typu niebezpieczeństw dostrzegana była niejednokrotnie z różnej perspektywy problemowej. Ludzi będących w drodze znamiennie przestrzegał przed zagubieniem siebie między innymi św. Augustyn w $W y-$ znaniach: „Oto ludzie wędrują, aby podziwiać szczyty gór, spiętrzone fale morza, szeroko rozlane rzeki, ocean otaczający ziemię, obroty gwiazd. A siebie samych omijają, siebie nie podziwiają" "Trzeba przyznać, że autor niezwykle przekonująco skłaniał ludzi do doświadczania wartości samych siebie. Jednakże aby móc doświadczać takiego stanu rzeczy, nieodzowne jest podejmowanie trudu peregrynacji do wewnątrz siebie samego, być może w taki sposób, jak poetycko proponował Bolesław Leśmian w utworze pt. Tu jestem, a mianowicie: „Zewsząd idę ku sobie, wszędzie na się czekam, Tu się spieszę dośpiewnie, tam - docisznie zwlekam"8.

${ }_{5}$ Zagadnienie drogi do doświadczania wartości samego siebie podejmowałam szerzej w innych miejscach. Zob. np. Urszula Ostrowska, Doświadczanie wartości edukacyjnych w szkole wyższej (Bydgoszcz: Wydawnictwo Uczelniane Akademii Techniczno-Rolniczej w Bydgoszczy, 1998), 57-94 i passim; Urszula Ostrowska, „Doświadczanie wartości samego siebie przez podmioty edukacyjne szkoły wyższej w toku badań jakościowych", w: Doświadczanie wartości samego siebie w procesach edukacyjnych, red. Andrzej M. Tchorzewski (Bydgoszcz: Wydawnictwo Uczelniane WSP w Bydgoszczy, 1997), 84-97.

${ }^{6}$ Zob. Józef Tischner, Wędrówki w krainę filozofów (Kraków: Znak, 2008).

${ }^{7}$ Augustyn, Wyznania, tłum. Zygmunt Kubiak (Kraków: Znak, 2000), X, 8, 9 [272].

${ }^{8}$ Bolesław Leśmian, Z tamtej strony ciszy (Wrocław: Biuro Literackie, 2012), 81. 
Owa droga do wewnątrz siebie to w istocie doświadczanie własnego Ja, które - jak wiarygodnie uzasadniał filozof nadziei - staje się dla człowieka swoistą wartością, przeżywa on bowiem samego siebie jako pewną szczególną wartość i zarazem dzięki temu nabywa zdolności do doświadczania innych wartości. A ponadto dopowiadał w innym miejscu, że droga prowadzi do spotkania z samym sobą, które „wprowadza człowieka w głąb wielkich tajemnic istnienia, gdzie rodzą się pytania o sens i bezsens wszystkiego, co jest"9. Człowiek wszakże - według Tischnera przywołującego Kartezjusza w Wędrówkach w kraine filozofów - w swym subiektywnym wnętrzu jest wielki oraz suwerenny i może uczyć się od samego siebie ${ }^{10}$.

Zasygnalizowany tu trop autonomiczności inspirująco prowadzi ku następnej kategorii rozważanej triady, a mianowicie ku wolności.

\section{Wolność}

Od zarania dziejów kwestia wolności jest dla ludzkości tematem odwiecznym. Nie tylko mówi się o niej od zawsze, ale zazwyczaj czyni wszystko, co tylko możliwe, aby ją zdobywać, umacniać, bronić, a po utracie odzyskać. Polakom szczególne rozumienie wolności wyznaczały narodowe i państwowe dzieje, zapisując nas w opinii międzynarodowej jako naród przede wszystkim miłujący wolność. Z uwagi na szczupłość miejsca pominę tu aspekty leksykalne oraz im towarzyszące, które eksplorowałam w innym miejscu ${ }^{11}$. Niemniej na użytek niniejszych rozważań uzasadnione zdaje się przywołanie stwierdzenia, iż człowiek jako element ekosystemu oraz część społeczeństwa, niezależnie od doświadczanego samopoczucia wolności, nie jest i nie może być absolutnie, całkowicie en bloc wolny, niezależny. Otóż może doświadczać wolności tylko w pewnym stopniu i zakresie, czyli w jakiejś części być niezależny. Wolność całkowita możliwa jest do zaistnienia tylko w wyobraźni lub w teorii. Nic przeto dziwnego, że wolność należy do tych pojęć, które skupiły wokół siebie wiele kontrowersji i definicji. W zróżnicowanym bogactwie niemal 200 określeń tego pojęcia angielski filozof Isaiah Berlin w swym klasycznym eseju poświęconym wolności rozróżnia tylko dwa jego zasadnicze znaczenia: wolność negatywną od (brak zakazów i nakazów) i wolność pozytywną do (dyspozycja jednostki do stanowienia

\footnotetext{
9 Józef Tischner, „Bezdroża spotkań”, Analecta Cracoviensia 12 (1980): 142.

10 Zob. Tischner, Wędrówki.

${ }^{11}$ Zob. Ostrowska, Doświadczanie, 189-256.
} 
i wpływania na rzeczywistość, możliwość dokonywania wyborów przez wewnątrzsterowny podmiot) ${ }^{12}$. Przywołuję tu brytyjskiego historyka idei i filozofa będącego zwolennikiem liberalizmu z tej racji, że filozof z Krakowa - jakkolwiek odrębnego większego dzieła filozoficznego poświęconego wyłącznie wolności nie napisał - to jednak w swoich różnych tekstach wielokrotnie wypowiadał się na bez wątpienia pretendujący do priorytetowych w jego rozważaniach temat, odnosząc się także do obu wymiarów tego fenomenu artykułowanych w eseju Berlina ${ }^{13}$.

Wprawdzie krakowski filozof miał przekonanie, że wolność nie jest wartością najważniejszą, której wszystkie inne powinny być podporządkowane, to jednak niekiedy można odnieść wrażenie, iż przypisywał on wolności szczególne miejsce w świecie wartości i najważniejszą rolę w życiu człowieka, skoro na przykład pisał następująco: „Wolność to ta jedyna w swoim rodzaju wartość etyczna, od której realizacji zależy realizacja wszystkich innych wartości osobowych"14.

Rzecz oczywista, obaj przywołani tu autorzy podejmujący zagadnienie wolności są przedstawicielami odmiennych nurtów myślenia (liberał i tradycja katolicka), ale zgodnie przypisywali temu fenomenowi ogromną rolę w życiu. Obaj wyrażali przekonanie, że przymus uniemożliwia pełny rozwój człowieka według własnej woli. Otóż Tischner uzasadniał, że wolność negatywna - będąc niezbędnym warunkiem pełni wolności - jest niewystarczająca, toteż wskazywał na nieodzowność zaistnienia wolności pozytywnej. Wiadomo wszakże, iż ani wolność negatywna, ani wolność pozytywna nie jest stanem trwałym bądź rozwiązującym szereg problemów natury filozoficznej, i to niezależnie od tego, czy rozpatruje się je łącznie, czy rozdzielnie, czy też zamiennie. Mając tego stanu rzeczy świadomość, autor Historii filozofii po góralsku ${ }^{15}$ mawiał, że poczucie wolności, jakie posiada, zawdzięcza przede wszystkim bliskiemu mu krajobrazowi górskiemu. Zastrzegał przy tym, że jakkolwiek człowiek przez całe życie nie jest w stanie chodzić po

12 Por. Isaiah Berlin, Cztery eseje o wolności, thum. Hanna Bartoszewicz, Daniel Grinberg (Warszawa: Wydawnictwo Naukowe PWN, 1994), 33-59, 182-233.

${ }^{13} \mathrm{Z}$ wczesnego okresu twórczości Tischnera znane są dwie mniejszych rozmiarów rozprawy na temat wolności, a mianowicie: „W poszukiwaniu istoty wolności” (1970) oraz „Ethos wolności” (1975), które - obok takich tekstów jak: „Chochoł sarmackiej melancholii”, „Refleksje o etyce pracy” oraz „Wiązania nadziei” - zamieszczone zostały w zbiorze zatytułowanym Świat ludzkiej nadziei. Wybór szkiców filozoficznych 1966-1975 (Kraków: Znak, 1994).

14 Józef Tischner, Polski młyn (Kraków: Instytut Wydawniczy Księży Misjonarzy „Nasza Przyszłość", 1991), 23.

15 Józef Tischner, Historia filozofii po góralsku (Kraków: Znak, 2017). 
szczytach, to jednak litości godzien jest ten, kto na szczyt nigdy nie wszedł, metaforycznie odnosił się w tenże sposób do szczytu duszy ludzkiej (nie do szczytu góry) ${ }^{16}$.

Dla filozofa nadziei wolność jest nade wszystko sposobem istnienia dobra ${ }^{17}$, albowiem drogę do wolności wytycza właśnie owo dobro, które jest spełniane przez człowieka. Pisząc na temat wolności, Tischner zastrzegał, iż nie jest ona jednym z neutralnych aksjologicznie faktów, lecz „fascynuje i napawa lękiem, dlatego zmusza, by nasza postawa wobec niej nie była nieokreślona" ${ }^{18}$. Nacechowanie aksjologiczne wolności zostało przez „myśliciela według wartości” zasygnalizowane następująco:

Wolność jest wartością zadaną człowiekowi do realizacji. Człowiek nie tyle jest wolny, ile staje się wolny albo wyrzeka się własnej wolności. Wolność jako wartość ma dwa aspekty: jest wolnością od czegoś (niezależnością) i wolnością do czegoś (służbą). Niezależność odnosi się przede wszystkim do przemocy, służba odnosi się do wartości ${ }^{19}$.

Zatem człowiek staje się wolny jedynie wtenczas, gdy czyni dobro, a zwłaszcza jeśli realizuje wartości wyższe (duchowe, religijne). Niemniej życie nie stawia człowieka wyłącznie wobec wyborów między dobrem a złem, ale także skłania go ku różnym sposobom realizowania dobra. Dzięki wolności człowiek na drodze do niej może podążać rozmaitymi ścieżkami dobra, kreując na wiele sposobów swoje życie. Jednakże człowiek nie jest całkowicie wolny, jest wolny wobec dobra i zła, wobec tego „być wolnym oznacza przede wszystkim być wolnym w stosunku do dobra i zła" ${ }^{20}$. Natomiast jeśli człowiek wybiera zło, to znaczy, że nie do końca udźwignął ciężar swojej wolności i wyjątkowości.

Wolność sytuuje się w złożonym wielorako świecie „prawdy i nieprawdy, szczęścia i nieszczęścia, sprawiedliwości i niesprawiedliwości, uczciwo-

16 Józef Tischner, „Wędrówki w krainę filozofów”, https://www.youtube.com/watch?v=E4xaghKKCfI [dostęp: 10.01.2018].

17 Józef Tischner, Myślenie w żywiole piękna (Kraków: Znak, 2004), 335; Józef Tischner, Wezwanie do wolności (Kraków: Znak, 1985), 204; Józef Tischner, Spór o istnienie człowieka (Kraków: Znak, 1998), 315-318; Józef Tischner, Spowiedź rewolucjonisty (Kraków: Znak, 1991), 35 .

18 Tischner, Świat, 149.

19 Józef Tischner, „Wolność”, w: Katolicyzm A-Z, red. Zbigniew Pawlak (Poznań: Księgarnia św. Wojciecha, 1999), 392.

20 Tischner, Spór, 349. 
ści i nieuczciwości, honoru i podłości”"21. Człowiek na drodze do wolności musi zmagać się z rozmaitymi ekstremami. Stawiając czoła owym sprzecznościom, nie zawsze jest $\mathrm{w}$ stanie $\mathrm{w}$ sposób satysfakcjonujący pokonywać napotykane przeszkody do tego stopnia nawet, że wolność może okazać się dla niego „ciężarem, którego pragnął się pozbyć. Wolność znaczy odpowiedzialność, a odpowiedzialność rodzi winę. Człowiek, choć uchodzi za niewinnego, wybiera ucieczkę od wolności" ${ }^{\prime 2}$. Nic przeto dziwnego, że takiemu stanowi rzeczy filozof ,wzywający do wolności” przypisuje miano „nieszczęsnego daru wolności”, który bywa niejednokrotnie powodowany lękiem. Podążając tropem „etosu wolności”, aczkolwiek nie uwolniwszy się całkowicie od wątpliwości, Tischner stwierdził: „Może się mylę, ale często bardzo często - widzę, jak nasz lęk przed wolnością staje się większy niż lęk przed przemocą" 23 .

Nadto jeszcze człowieka będącego na drodze do wolności zniewolić mogą rozmaite nałogi tudzież prymitywne instynkty, pożądania, słabości ludzkie, a także wewnętrzne zniewolenie osoby czyniącej zło. Niemniej Tischner zastrzegał zarazem, iż dobro nawet w sensie najważniejszego dla człowieka celu musi być wyzwolone z wszelkiej konieczności, jako że nikogo nie można zmusić do tego, aby był dobrym. W konsekwencji o relacji dobra z wolnością wypowiedział się następująco: „Gdyby działania dobra unicestwiła wolność, byłoby złym działaniem"24.

W ślad za tym stwierdził, że wolność jest najpierw i przede wszystkim kategorią dramatyczną, pojawiając się między ludźmi wolnymi w stosunku do siebie ${ }^{25}$. Dla filozofa nadziei dobro jest tożsame z Bogiem, dlatego uzasadniał, iż: „Bóg jest najwyższym «budzicielem» wolności. Jest najwyższym Dobrem. Między Bogiem i człowiekiem jest więź bez przemocy, bo łaska pochłonęła przemoc”26. I dodawał: „Wolność człowieka jest «odbiciem» wolności Boga. Bóg jest nie tylko «zewnętrznie», ale i «wewnętrznie» wolny"27.

Skoro wolność jest najpierw kategorią dramatyczną, zatem pora podjąć trzeci trop rozważanej problematyki, to jest zagadnienie dramatu.

\footnotetext{
21 Tischner, Świat, 157.

22 Józef Tischner, Wybrane problemy filozofii człowieka (Kraków: Znak, 1985), 93.

23 Józef Tischner, Nieszczęsny dar wolności (Kraków: Znak, 1985), 7.

${ }^{24}$ Tischner, Spór, 287, 318.

25 Tamże, 298.

26 Józef Tischner, Filozofia człowieka dla duszpasterzy i artystów (Kraków: Wydawnictwo Naukowe PAT, 1991), 127.

27 Tischner, Spór, 318.
} 


\section{Dramat*}

Powszechnie wiadomo, iż dramat (gr. drama - „czynność, akcja”) obok liryki i epiki - to bogaty w elementy strukturalne (takie jak na przykład akcja, akt, prolog, dialog, epilog, scena, węzeł dramatyczny etc.) jeden $\mathrm{z}$ trzech rodzajów literackich, będący w istocie swej rodzajem sztuki na granicy teatru i literatury, tylko bowiem w warstwie słownej zaliczany jest do literatury, natomiast w realizacji widowiskowej należy do wielowarstwowej sztuki teatralnej ${ }^{28}$.

Podążając tropem „myślenia w żywiole piękna”, Tischner jako wielki wielbiciel teatru, często w nim bywał, pisał również teksty do premier teatralnych, prowadził seminaria i wykłady z filozofii dramatu w Państwowej Wyższej Szkole Teatralnej w Krakowie na Wydziale Reżyserii oraz wykłady monograficzne z filozofii na Wydziale Filologicznym Uniwersytetu Jagiellońskiego. Te zajęcia odgrywały znaczącą rolę w zakresie rozwoju jego poglądów i twórczości. Zwłaszcza od artystów i reżyserów teatralnych czerpał wielorakie inspiracje oraz impulsy do filozoficznych rozważań. Przy czym przekonująco nie sprowadzał dramatu wyłącznie do kategorii literackiej oraz nie zamykał w całej rozciągłości w przestrzeni kultury, lecz przypisywał mu znaczącą rangę w wytyczaniu drogi do wolności wpisującej się w orbitę oryginalnej filozofii człowieka.

Człowiek bowiem wzbudzał szczególne zainteresowanie twórcy filozofii dramatu nie tyle jako osoba grająca w dramacie oraz jako zajmujący wyznaczone miejsce na scenie aktor, lecz przede wszystkim jako będący istotą dramatyczną podmiot. Podmiot, który nie tyle gra, ile uczestniczy w drama-

* Problematyka Tischnerowkiej koncepcji filozofii dramatu stanowi przedmiot zainteresowania dla dość licznego grona badaczy piszących na ten temat, zob. np.: Tadeusz Gadacz, „Problem zła w filozofii Józefa Tischnera”, Horyzonty Wychowania 4 (2005): 21-40; Witold P. Glinkowski, „Problem sceny w tischnerowskiej filozofii dramatu”, Analiza i Egzystencja 34 (2016): 71-90; Dobrosław Kot, „Tischnerowska filozofia sceny”, Colloquia Communia 1-2 (2005): 123-132; Bogdan Trocha, Przestrzeń dramatu jako kategoria filozoficzna. Studium teorii przestrzeni Józefa Tischnera (Zielona Góra: Dom Wydawniczy Gest, 2000); Jan Wadowski, Dramat pytań egzystencjalnych. Ks. Józefa Tischnera filozofia dramatu jako próba odpowiedzi na pytania egzystencjalne (Wrocław: Wyd. Papieskiego Wydziału Teologicznego, 1999).

${ }^{28}$ Zob. Stanisław Sierotwiński, Stownik terminów literackich. Teoria i nauki pomocnicze literatury (Wrocław-Warszawa-Kraków: Zakład Narodowy Imienia Ossolińskich. Wydawnictwo Polskiej Akademii Nauk, 1970), 72. W podobnej konwencji definiują ów termin inne źródła leksykalne. 
cie obejmującym swym zakresem całokształt ludzkiego istnienia, wszystkie możliwe warianty „bycia w świecie”, zwłaszcza jako osoba dokonująca wyborów etycznych w horyzoncie sceny. Tak więc będący istotą dramatyczną człowiek doświadcza swojej egzystencji dramatycznie, przeżywając swoje życie jako dramat, bo „być istotą dramatyczną znaczy: przeżywać dany czas, mając wokół siebie innych ludzi i ziemię jako scenę pod stopami”29. Tischner w ślad za tym uzasadniał swoje stanowisko, wymieniając triadę uwarunkowań egzystencji dramatycznej: „Człowiek nie byłby egzystencją dramatyczną, gdyby nie trzy czynniki: otwarcie na innego człowieka, otwarcie na scenę dramatu i na przepływający czas" ${ }^{\prime 30}$. Uwrażliwiał zarazem, że podmiot dramatu zyskuje zdolność wyrażania jakiejś prawdy o sobie samym dopiero w relacji z drugim człowiekiem, albowiem: „Byt-dla-siebie staje się sobą poprzez inne bycie-dla-siebie. Jestem dla-siebie poprzez ciebie. I ty jesteś dla-siebie poprzez mnie" ${ }^{31}$. Zastrzegał przy tym, iż dramat warunkuje uczłowieczenie, znamiennie rzutując na ludzkie doświadczanie rzeczywistości, które spełnia się w spektrum „myślenia według wartości”, toteż z tej racji roztacza kontekst aksjologiczny, społeczny oraz ujawnia dramatyczne źródło.

„Fenomenolog spotkania" 32 postrzegał scenę jako konstytutywną kategorię stanowiącą miejsce dla dziejącego się dramatu ludzkiej egzystencji, kierującego się racjami dramatycznymi. Spotykający się w przestrzeni sceny ludzie z jednej strony są wielorako uwarunkowani, z drugiej jako wolni podejmują decyzje dobre i złe. W konsekwencji kluczową przesłanką dla Tischnerowskiego toku myślenia jest ,jakość bólu ludzkiego, który chce filozofia wyrazić i któremu chce zaradzić" ${ }^{33}$ za sprawą dziejących się wydarzeń o wymiarze horyzontalnym, ale także z racji otwierania się na wymiar wertykalny (transcendencja) - umożliwiający doświadczenie sacrum. Niemniej Tischner postrzega scenę głównie przez pryzmat płaszczyzny spotkań i przestrzeni wolności, „, której człowiek szuka sobie domu, chleba, Boga, i w której znajduje cmentarz"34. Nie pretenduje wszakże ani do nadawania kierunku dramatowi, ani nie aspiruje do podstaw przesądzania o tym, czy nastąpi potępienie, czy ocalenie, natomiast uwyraźnia rolę dialogu, jako że:

\footnotetext{
29 Józef Tischner, Filozofia dramatu (Kraków: Znak, 2012), 7-8.

30 Tamże.

31 Tischner, Świat, 173.

32 Józef Tischner, „Fenomenologia spotkania”, Analecta Cracoviensia 1 (1978): 73-98.

33 Józef Tischner, Myślenie wedtug wartości (Kraków: Znak, 1993), 13.

34 Tischner, Filozofia dramatu, 12.
} 
„Doświadczenie ziemi jako sceny nie jest [...] bezpośrednie, lecz zapośredniczone przez dialog" 35 .

Każdej egzystencji ludzkiej towarzyszy dramatyczne znamię z racji konieczności dokonywania przez człowieka wyborów i następstw błędnych decyzji w przestrzeni rozstrzygnięć między dobrem a złem, prawdą a fałszem, pięknem a brzydotą, szczęściem a tragedią, sprawiedliwością a niesprawiedliwością, uczciwością a nieuczciwością, honorem a podłością, sacrum a profanum, niebem a ziemią oraz między innymi ekstremami.

Przeciwieństwem ludzkiej wolności mającej wymiar aksjologiczny jest zniewolenie, w tym towarzyszące człowiekowi fatum. Jednakże to nie fatum decyduje o tragedii człowieka oznaczającej zwycięstwo zła nad dobrem, lecz dokonywane przez uczestników dramatu wybory wartości etycznych. Tenże ludzki dramat w ujęciu zaangażowanego duszpasterza Tischnera ma wymiar religijny z racji szczególnej relacji człowieka z Absolutem, czyli z Bogiem. Ochronę człowieka przed zwycięstwem zła ewentualnie przed niewolą fatum stanowi łaska pochodząca od Boga ${ }^{36}$.

Kluczowe przesłanki konstruowania dramatycznej drogi do wolności jako sposobu istnienia dobra i czynienia dobra wyznaczają liczne uwarunkowania, które Tischner w dość rozproszony sposób zawarł w swoich dziełach, zapewne inspirująco pozostawiając podejście systemowe do tychże kwestii odbiorcom dzieł podejmujących się niełatwych prób rekonstrukcji jego poglądów w tym zakresie ${ }^{37}$. Otóż z perspektywy rozważań przeprowadzonych w niniejszym tekście można w odniesieniu do zagadnienia dramatycznej drogi wolności jako czynienia dobra wskazać na następujące konstytutywne przesłania twórcy filozofii dramatu:

1. Wyzwalanie się z lęków (na przykład przed śmiercią, przed innymi) za sprawą pozyskania nadziei ${ }^{38}$.

2. Pokora będąca przeciwieństwem samozakłamania i pychy oraz bycie w prawdzie ${ }^{39}$.

35 Tamże, 180.

36 Zob. Tischner, Myślenie w żywiole, 153-154.

${ }^{37}$ Interesującą próbę rekonstrukcji Tischnerowskiej ,filozofii wolności” zaprezentował Wojciech Załuski w tekście pt. „Wolność jako sposób istnienia dobra. O filozofii wolności Józefa Tischnera", Studia z Filozofii Polskiej 10 (2015): 89-110.

38 Tischner, Spowiedź, 41; Tischner, Myślenie wedtug, 439-440.

39 Józef Tischner, „Etyka wartości i nadziei”, w: Józef Tischner, Jan A. Kłoczowski, Wobec wartości (Poznań: W Drodze, 2001), 112. 
3. Przezwyciężanie „logiki odwetu"40 stanowiące przejaw wolności szczególnie głębokiej za sprawą urzeczywistniania dobra nie tylko w odpowiedzi na dobro innych osób, ale także w sensie odpowiadania dobrem na doświadczane zło, także przebaczanie doznanych krzywd oraz przyznawanie się do winy ${ }^{41}$.

4. Wspaniałomyślność, to jest bezinteresowność w zaświadczaniu dobra, otwierająca przestrzeń dla ethosu wolności ${ }^{42}$, jako że „We wspaniałomyślności wolność dochodzi do swej najgłębszej prawdy. Dla analizy natury wolności jest to stwierdzenie o fundamentalnym znaczeniu"43.

5. Wychowanie jako proces wyzwalania wolności, albowiem ,najgłębszym problemem wychowawczym nie jest to, w jaki sposób panować nad człowiekiem, ale w jaki sposób obudzić w nim człowieczeństwo. A człowieczeństwem tym jest wolność" 44 .

Tischnerowska filozofia dramatu, sytuująca w centrum rozważań człowieka i jego codzienne doświadczenia, ma związek z teatrem w sensie postrzegania ludzkiego losu jako dziejącego się dramatu. Fenomenologicznie opisuje człowieka wobec bytu, wobec innego człowieka, wobec Boga, używając pojęć teatralnych jako metafor. Namysł nad egzystencją wyjątkowego w swej niepowtarzalności człowieka wymaga odpowiedniego języka, a w przypadku filozofii dramatu jest to język metaforyczny - „, w wętrza metafory". Dramat pojawia się i trwa jako funkcja dialogu osób zwracających się do siebie, świat jest sceną tylko jako przestrzeń międzyludzkich spotkań - realnych spotkań osób, a doświadczenie świata jest zapośredniczone dialogicznie i tym samym dramatycznie.

\section{Uwagi podsumowujące}

Ksiądz profesor Józef Tischner nie stworzył systemowej filozofii wolności, nie skonstruował uporządkowanej drogi do wolności jako dramatu, ale za sprawą jego dzieł, zwłaszcza Filozofii dramatu, można jego poglądy

\footnotetext{
40 Tischner, Spór, 319.

${ }^{41}$ Zob. Tischner, Myślenie wedtug, 383-391.

42 Józef Tischner, „Ethos wolności”, Znak 2 (1975): 158.

${ }^{43}$ Tischner, Spór, 334.

44 Józef Tischner, „O panowaniu nad Drugim”, https://www.youtube.com/watch?v= 31QHB0KCN1s [dostęp: 10.01.2018].
} 
rekonstruować oraz odczytywać płynące z nich przesłanie. Być może taki w zamyśle był cel ,filozofa nadziei” skłaniającego odbiorców jego spuścizny do aktywnego włączenia się w ów wielki, trwający nieustannie dyskurs na temat człowieka i jego świata, istoty zaświadczającej swoje człowieczeństwo. Tischnerowska koncepcja drogi do wolności jako dramatu jest w istocie swej filozoficzną refleksją poświęconą trosce o człowieka, o człowieczeństwo. Konstruując architektonikę niezwykle oryginalnej, interesującej koncepcji człowieka, „myśliciel według wartości” zachęcał motywująco do spotkań w horyzoncie agatologicznym i aksjologicznym oraz do dialogu, którego był entuzjastą, a także propagatorem. Ksiądz profesor Józef Tischner to nie tylko zaangażowany duszpasterz, wybitny przedstawiciel polskiego Kościoła, ale również znakomity filozof i nauczyciel akademicki, wnikliwy obserwator i komentator życia publicznego, animator kultury podhalańskiej i jej dialektu, a także wychowawca wielu ludzi teatru, w tym polskich reżyserów i aktorów.

$\mathrm{Z}$ dużą dozą humoru mówił o sobie: ,jestem najpierw człowiekiem, potem filozofem, potem długo, długo nic, a dopiero potem księdzem" ${ }^{45}$. W godny podziwu sposób wzbudzał zaufanie jako człowiek, inspirował i nadal inspiruje jako filozof, zachwycał studentów kilku uczelni interesującymi wykładami, uczył dojrzałej wiary jako ksiądz, nawiązywał przyjazne relacje z ludźmi, aczkolwiek nie zawsze i nie wszędzie spotykał się ze zrozumieniem. $\mathrm{Z}$ wielu względów przywodzi to na pamięć postać cenionego przez filozofa nadziei, odważnie wyrażającego swoją refleksję filozoficzną, wyprzedzającego swoją epokę, poetę i filozofa Cypriana K. Norwida, który doświadczając niezrozumienia przez jemu współczesnych, miał przekonanie, że pisze dla „późnych wnuków”, którzy będą w stanie docenić jego geniusz.

Jeśli wolą Tischnera było inspirować do kontynuacji jego własnych myśli, to na owej drodze do wolności dostrzegam potrzebę dopisania jeszcze jednego aktu tego fascynującego dramatu, a mianowicie dla wolności egzystencjalnej w byciu w odniesieniu do człowieka - niewyzwalającego się od, jak w przypadku wolności negatywnej, i niepretendującego do, jak w sytuacji wolności pozytywnej - lecz człowieka, który osiągając pojęciowe bogactwo rzeczywistości, ukierunkowany twórczo - odpowiedzialnie interpretuje egzystencję, rozumie swój związek z bytem oraz znajduje sensowne odniesienie tejże wolności do świata wartości, świata, którego zasady uznaje, przestrzega, urzeczywistnia, współtworzy i wzbogaca aż do potencjonalnego kreowania ars vitae włącznie. Można przyjąć, że to bardzo ważny wymiar

\footnotetext{
45 Józef Tischner, Ksiądz na manowcach (Kraków: Znak, 1999), 6.
} 
wolności, z tej zwłaszcza racji, że sytuuje człowieka blisko samego siebie oraz zbliża go do innych, a nie oddala i nie dystansuje od/do tak, jak to ma miejsce w przypadku osoby pochłoniętej walką o wolność albo zdążającej w kierunku powziętego idealnego kresu emancypacyjnego wyzwalania się od czegoś i/lub pretendowania do czegoś. Wbrew pozorom perspektywa takiej wolności nie prowadzi do samowoli, lecz właśnie uświadamia - zgodnie z przesłaniem Seneki, iż: Libere decet, libere cui multum licet („Komu wolno wiele, temu najmniej przystoi być samowolnym").

Oto bowiem wolność, aby stała się wartością rzeczywistą, musi być autentycznie przez podmiot przeżyta, powinna być autentycznie doświadczona, jako że wolności nie można tylko mieć, lecz wolnym trzeba prawdziwie odpowiedzialne być, mając poczucie bycia wolnym. Tymczasem człowiek zdominowany przez działania wyzwalania się od tudzież pretendowania do nie ma kiedy doświadczać autentycznie wolności, rozsmakowywać się „w byciu” w wolności, ponieważ permanentnie do niej zmierza, ciągle walczy o nią, mając poczucie niedosytu emancypacyjnego. A kiedy nawet już ją prawie osiąga, to wówczas albo nie wie co począc z tym ,nieszczęsnym darem wolności", albo nadal odczuwa jej niedosyt, bo ta, do której prawie już dochodzi, wydaje się niedomknięta, niedookreślona, niedokończona i w rezultacie tegoż ponownie wciąga się w nurt zmagań, absorbujący prawie bez reszty trud walki, na nowo. Ostatecznie zmęczony ową walką rezygnuje, aby odpocząć, albo całkowicie zniechęca się i nie doświadcza tego, o co tak usilnie zabiegał, czemu poświęcił się prawie bez reszty ${ }^{46}$.

Konkluzja rozważań prowadzi ku stwierdzeniu, iż namysł nad intelektualnym dziedzictwem ks. prof. Józefa Tischnera, twórcy filozofii dramatu, autora rozpraw z filozofii współczesnej, etyki, aksjologii i filozofii człowieka, krytyka marksizmu, propagatora chrześcijaństwa otwartego na dialog, opartego na wolności, myśliciela wrażliwego na obecność każdego człowieka, wzbudzającego dobro autora kazań i gawęd góralskich, skłania do interdyscyplinarnego odczytywania jego spuścizny. Całokształt przebytej drogi rozważań z jednej strony uświadamia, jaką bogatą i zróżnicowaną działalność publicystyczną - literacką - filozoficzną - społeczną - duszpasterską - dydaktyczną - medialną uprawiał filozof nadziei, będąc niekwestionowanym autorytetem moralnym i jednym z najoryginalniejszych polskich myślicieli

46 Zagadnienie koncepcji „,wolności w byciu” podejmowałam z perspektywy edukacyjnej. Zob. Urszula Ostrowska, ,Retoryka nieemancypacyjnej koncepcji wolności jako problem edukacyjny", w: Wolność jako wartość i problem edukacyjny, red. Andrzej M. de Tchorzewski (Bydgoszcz: Wydawnictwo „WERS”. 1999), 87-98. 
$\mathrm{XX}$ wieku, z drugiej strony wpisuje się znamiennie w szlachetną ideę tradycji ceniącej to, co ważne i doniosłe dla współczesności oraz znacząco wpisujące się w projekcję przyszłości.

\section{The Pathway to Freedom as a Drama. Around Tischner's Concept of the Philosophy of Freedom (Summary)}

Freedom constitutes one of the basic issues of ethical reflection of Józef Tischner. Tischner did not create a systemic philosophy of freedom, he did not construct an orderly way to freedom as a drama. As a result of deepening our knowledge of his works, the Philosophy of drama, in particular, we can reconstruct his views and read the message hidden within them. Perhaps it was intentionally intended by the philosopher of hope to induce recipients of his legacy to participate actively in this great, ongoing discourse on the subject of man and his world - the being testifying to his own humanity.

Keywords: pathway; freedom; drama; philosophy; man; reconstruction; metaphor; hope; humanity.

\section{Droga do wolności jako dramat. Wokół Tischnerowskiej koncepcji filozofii wolności (Streszczenie)}

Wolność stanowi jeden z głównych problemów refleksji etycznej Józefa Tischnera. Tischner nie stworzył systemowej filozofii wolności, nie skonstruował uporządkowanej drogi do wolności jako dramatu. Zgłębiając jego dzieła, zwłaszcza Filozofię dramatu, można jego poglądy rekonstruować, można odczytywać płynące z nich przesłanie. Być może taki w zamyśle był zamiar filozofa nadziei, skłaniającego odbiorców jego spuścizny do aktywnego włączenia się w ów wielki, trwający nieustannie dyskurs na temat człowieka i jego świata, istoty zaświadczającej swoje człowieczeństwo.

Słowa kluczowe: droga; wolność; dramat; filozofia; człowiek; rekonstrukcja; metafora; nadzieja; człowieczeństwo. 


\section{Bibliografia}

Augustyn. Wyznania, tłum. Zygmunt Kubiak. Kraków: Wydawnictwo Znak, 2000.

Berlin, Isaiah. Cztery eseje o wolności, thum. Hanna Bartoszewicz, Daniel Grinberg. Warszawa: Wydawnictwo Naukowe PWN, 1994.

Gadacz, Tadeusz. „Problem zła w filozofii Józefa Tischnera”. Horyzonty Wychowania 4 (2005): 21-40.

Glinkowski, Witold P. „Problem sceny w tischnerowskiej filozofii dramatu”. Analiza i Egzystencja 34 (2016): 71-90.

Kot, Dobrosław. ,Tischnerowska filozofia sceny”. Colloquia Communia 1-2 (2005): 123-132.

Leśmian, Bolesław. Z tamtej strony ciszy. Wrocław: Biuro Literackie, 2012.

Ostrowska, Urszula. Dialog w pedagogicznym badaniu jakościowym. Kraków: Oficyna Wydawnicza „Impuls”, 2000.

Ostrowska, Urszula. Doświadczanie wartości edukacyjnych w szkole wyższej. Bydgoszcz: Wydawnictwo Uczelniane Akademii Techniczno-Rolniczej w Bydgoszczy, 1998.

Ostrowska, Urszula. „Doświadczanie wartości samego siebie przez podmioty edukacyjne szkoły wyższej w toku badań jakościowych". W: Doświadczanie wartości samego siebie w procesach edukacyjnych, red. Andrzej M. Tchorzewski, 84-97. Bydgoszcz: Wydawnictwo Uczelniane WSP w Bydgoszczy, 1997.

Ostrowska, Urszula. „Retoryka nieemancypacyjnej koncepcji wolności jako problem edukacyjny". W: Wolność jako wartość i problem edukacyjny, red. Andrzej M. de Tchorzewski, 87-98. Bydgoszcz: Wydawnictwo „WERS”, 1999.

Sierotwiński, Stanisław. Słownik terminów literackich. Teoria i nauki pomocnicze literatury. Wrocław-Warszawa-Kraków: Zakład Narodowy Imienia Ossolińskich, Wydawnictwo Polskiej Akademii Nauk, 1970.

Tischner, Józef. „Bezdroża spotkań”. Analecta Cracoviensia 12 (1980): 137-172.

Tischner, Józef. „Ethos wolności”. Znak 2 (1975): 185-194.

Tischner, Józef. „Etyka wartości i nadziei”. W: Józef Tischner, Jan A. Kłoczowski, Wobec wartości, 55-149. Poznań: W Drodze, 2001.

Tischner, Józef. „Fenomenologia spotkania”. Analecta Cracoviensia 1 (1978): 73 -98 .

Tischner, Józef. „O panowaniu nad Drugim”. https://www.youtube.com/watch?v= 31QHB0KCN1s [dostęp: 10.01.2018].

Tischner, Józef. „Wędrówki w krainę filozofów”. https://www.youtube.com/watch?v =E4xaghKKCfI [dostęp: 10.01.2018]. 
Tischner, Józef. „Wolność”. W: Katolicyzm A-Z, red. Zbigniew Pawlak, 392. Poznań: Księgarnia św. Wojciecha, 1999.

Tischner, Józef. Filozofia człowieka dla duszpasterzy i artystów. Kraków: Wydawnictwo Naukowe PAT, 1991.

Tischner, Józef. Filozofia dramatu. Kraków: Znak, 1993.

Tischner, Józef. Filozofia dramatu. Kraków: Znak, 2012.

Tischner, Józef. Historia filozofii po góralsku. Kraków: Znak, 2017.

Tischner, Józef. Ksiądz na manowcach. Kraków: Znak, 1999.

Tischner, Józef. Myślenie w żywiole piękna. Kraków: Znak, 2004.

Tischner, Józef. Myślenie wedlug wartości. Kraków: Znak, 1993.

Tischner, Józef. Nieszczęsny dar wolności. Kraków: Znak, 1985.

Tischner, Józef. Polski młyn. Kraków: Instytut Wydawniczy Księży Misjonarzy „Nasza Przyszłość", 1991.

Tischner, Józef. Spowiedź rewolucjonisty. Kraków: Znak, 1991.

Tischner, Józef. Spór o istnienie człowieka. Kraków: Znak, 1998.

Tischner, Józef. Świat ludzkiej nadziei. Kraków: Znak, 1992.

Tischner, Józef. Wezwanie do wolności. Kraków: Znak, 1985.

Tischner, Józef. Wędrówki w krainę filozofów. Kraków: Znak, 2008.

Tischner, Józef. Wybrane problemy filozofii człowieka. Kraków: Znak, 1985.

Trocha, Bogdan. Przestrzeń dramatu jako kategoria filozoficzna. Studium teorii przestrzeni Józefa Tischnera. Zielona Góra: Dom Wydawniczy Gest, 2000.

Wadowski, Jan. Dramat pytań egzystencjalnych. Ks. Józefa Tischnera filozofia dramatu jako próba odpowiedzi na pytania egzystencjalne. Wrocław: Wydawnictwo Papieskiego Wydziału Teologicznego, 1999.

Załuski, Wojciech. „Wolność jako sposób istnienia dobra. O filozofii wolności Józefa Tischnera". Studia z Filozofii Polskiej 10 (2015): 89-110. 